Jurnal Sulolipu : Media Komunikasi Sivitas Akademika dan Masyarakat

Vol. 21 No. 12021

e-issn : 2622-6960, p-issn : 0854-624X

\title{
HUBUNGAN PERILAKU MASYARAKAT DENGAN KEBIASAAN BUANG AIR BESAR SEMBARANG DAN KEJADIAN PENYAKIT DIARE ( STUDI KEPUSTAKAAN )
}

Community Behavior Relationship With Any Defeat Habits And The Event Of Diarrhea

\author{
(Literature Study) \\ Ardina Syarda ${ }^{1}$, Juherah ${ }^{2}$ \\ 1,2Poltekkes Kemenkes Makassar \\ *)ardinasyarda012@gmail.com, 082293995013
}

\begin{abstract}
Provision of community sewage disposal facilities, especially in its implementation is not easy, because it involves the participation of the community which is usually very closely related to knowledge, attitudes, actions. This study aims to describe the relationship of public behavior with the habit of open defecation and the incidence of diarrheal disease. This type of research is literature study research with descriptive and cross sectional approaches.Data obtained from the results of the study will be presented textually / narratively and made GRID synthesis (Synthesis Table) and then analyzed.The results of this study indicate that 1) bowel behavior $(B A B)$ is associated with the incidence of diarrhea in the community in the village of Krajan, Jatinom District. 2) BehaviorOpen Defecation is associated with the occurrence of diarrhea in the Sambas District Sajad community. 3) Knowledge and attitude are the dominant variables that influence STBM behavior in the community in Inderalaya District. 4) Defecation behavior of Tanjung village has become a habit. 5) The relationship between motivstion for clean and healthy behavior (PHBS) with bowel habits (BAB) in Karangrowo village. The conclusion obtained from this study is that based on the results of 5 journals reviewed there is a relationship between community behavior with open defecation habits with the incidence of diarrheal disease.

Keywords: Defecation Behavior, Diarrhea
\end{abstract}

\section{ABSTRAK}

Penyediaan sarana pembuangan tinja masyarakat terutama dalam pelaksanaannya tidaklah mudah, karena menyangkut peran serta masyarakat yang biasanya sangat erat kaitannya dengan pengetahuan, sikap, tindakan.Penelitian ini bertujuan untuk mendeskripsikan Hubungan perilaku masyarakat dengan kebiaasaan buang air besar sembarangan dan kejadian penyakit diare. Jenis penelitian yang digunakan adalah penelitian studi kepustakaan dengan pendekatan deskriptif dan Cross sectional. Data yang diperoleh dari hasil penelitian akan disajikan secara tekstular/narasi dan dibuat sintesis GRID (Tabel Sintesis) kemudian di analisis. Hasil penelitian ini menunjukkan bahwa 1) Perilaku buang air besar (BAB) berhubungan dengan kejadian diare pada masyarakat di desa Krajan, Kecamatan Jatinom. 2) Perilaku Open Defecation berhubungan dengan kejadian diare pada masyarakat Kecamatan Sajad Kabupaten Sambas. 3) Perilaku merupakan variabel dominan yang mempengaruhi perilaku STBM pada masyarakat di Kecamatan Inderalaya. 4) Perilaku buang air besar Desa Tanjung sudah menjadi kebiasaan. 5) Hubungan motivasi perilaku hidup bersih dan sehat (PHBS) dengan kebiasaan buang air besar (BAB) di desa Karangrowo. Kesimpulan yang didapatkan dari penelitian ini yaitu berdasarkan dari hasil 5 jurnal yang dikaji adalah ada hubungan perilaku masyarakat dengan kebiasaan buang air besar sembarangan dan kejadian penyakit diare.

Kata Kunci : Perilaku Buang Air Besar, Diare

\section{PENDAHULUAN}

Rencana pembangunan Jangka Menengah Nasional (RPJMN) tahun 2015-2019, kebijakan dalam pembangunan kesehatan lingkungan telah mendapat perhatian khusus. Hal ini tertuang dalam dokumen resmi RPJMN tahun 2015-2019, dimana Rencana Pembangunan Jangka Menengah Nasional harus berwawasan lingkungan, sesuai dengan tujuan pembangunan berkelanjutan dunia atau Suistanable Develotment Goals (SDGD). Beberapa target/tujuan SDGS yang terkait dengan lingkungan diantaranya tujuan 6 yaitu menjamin ketersediaan dan menajemen air dan sanitasi secara berkelanjutan dan tujuan 13 yaitu mengambil tindakan segera untuk memerangi perubahan iklim dan dampaknya. (Profil Kesehatan Indonesia, 2016).

Berdasarkan Dinas Kesehatan Provinsi Sulawesi Selatan penduduk dengan akses terhadap fasilitas sanitasi yang layak (Jamban sehat) di kab/kota yaitu : Jamban leher angsa $108,18 \%$, Jamban plengsengan $111,57 \%$, Jamban cemplung 62,18\%, Jamban komunal 82,17\%. (Dinas Kesehatan Prov.Sulawesi Selatan Tahun 2018)

Kasus diare yang ditemukan dan ditangani yang di laporkan oleh 46 puskesmas se Kota Makassar sampai dengan desember 2015sebanyak 28.257 kasus dengan angka kesakitan yaitu 20,07 per 1.0000 penduduk meningkat dari tahun 2014 yaitu 26.485 kasus dengan angka kesakitan yaitu 19,34 per 1.000 penduduk, kemudian menurun menurun dari tahun 2013 yaitu 28.908 kasus dengan angka kesakitan penyakit diare sebesar 21,8 per 1.000 penduduk.(Dinas Kesehatan Kota Makassar, 2015)

Berdasarkan data diatas, maka penulis tertarik meneliti dengan judul: "Hubungan Perilaku Masyarakat dengan Kebiasaan Buang Air Besar (BAB) sembarang dan Kejadian Penyakit Diare." 
Jurnal Sulolipu : Media Komunikasi Sivitas Akademika dan Masyarakat

Vol. 21 No. 12021

e-issn : 2622-6960, p-issn : 0854-624X

\section{METODE}

Jenis Penelitian

Jenis penelitian yang digunakan adalah penelitian studi kepustakaan dengan pendekatan deskriptif dan Cross sectional. Penelitian dilakukan dengan teknik pengumpulan data sehingga dapat diketahui Hubungan Perilaku Masyarakat Dengan Kebiasaan Buang Air Besar Sembarangan dan Kejadian Penyakit Diare.

\section{METODE PENGUMPULAN DATA}

Data sekunder diperoleh dari hasil penelusuran kepustakaan dan instansi berupa data penyakit, buku-buku, artikel, jurnal, hasil penelitian sebelumnya dan internet serta media informsi lainnya yang dianggap memiliki keterkaitan dengan penelitian ini.

\section{KRITERIA LITERATUR}

1. Kriteri Inklusi

Jurnal yang dipergunakan pada tahun 20112019

2. Kriteria Ekslusi

Pengurangan subjek data apabila pada jurnal yang didapatkan dari tahun tersebut sesuai dengan kriteria yang ditepatkan sebelumnya.

\section{PENGOLAHAN DAN PENYAJIAN DATA}

1. Pengolahan Data

Pengolahan data dilakukan dengan menggunakan alat elektronik berupa handphone, komputer atau dengan laptop dengan bantuan aplikasi pengolahan data dan angka.

2. Penyajian Data

Data yang diperoleh dari hasil penelitian akan disajikan secara tekstular/narasi dan dibuat sintesis GRID (Tabel Sintesis).

\section{ANALISA DATA}

Data hasil yang diperoleh ditabulasikan, kemudian di analisis dengan menggunakan analisis tabel sintesa.

HASIL

Hasil penelitian dari Ambar Winarti, Suci NurmalasaritentangHubungan Perilaku Buang Air Besar (Bab) Dengan Kejadian Diare Di Desa Krajan Kecamatan Jatinom Kabupaten Klaten
Tabel 1 Distribusi Responden Perilaku BAB di Desa Krajan

\begin{tabular}{ccc}
\hline Perilaku & Frekuensi & Persentase \\
\hline Benar & 64 & $65,3 \%$ \\
\hline Salah & 34 & $34,7 \%$ \\
\hline Total & 98 & $100,0 \%$ \\
\hline
\end{tabular}

Tabel 2 Distribusi Responden Diare di Desa Krajan

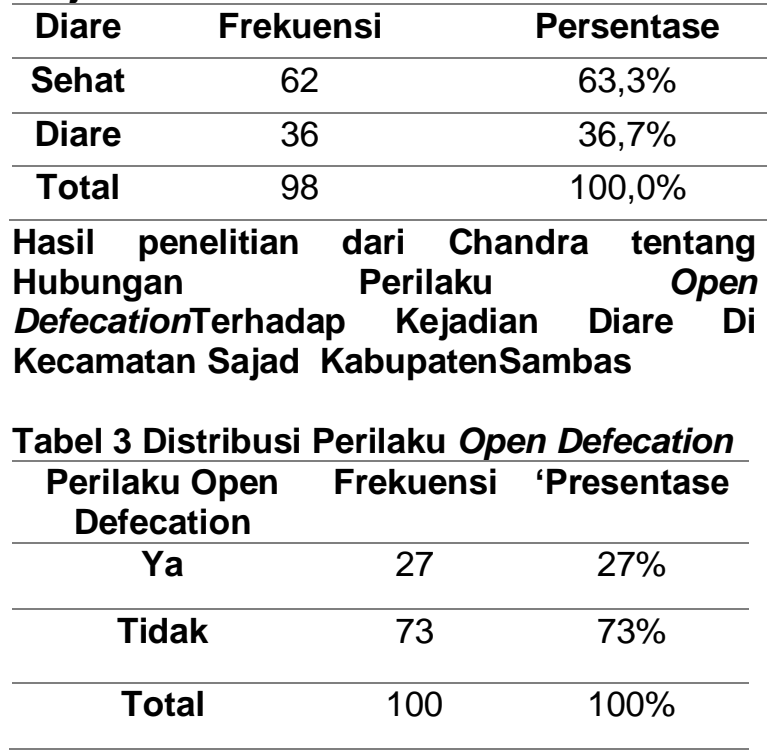

Tabel 4 Distribusi kejadian diare

\begin{tabular}{ccc}
\hline Diare & Frekuensi & Persentase \\
\hline Ya & 26 & $26 \%$ \\
\hline Tidak & 74 & $74 \%$ \\
\hline Total & 100 & $100 \%$ \\
\hline
\end{tabular}

Hasil penelitian dari Resti Irmalasari, Najmah,Nur Alam Fajar tentang Studi Komparatif Perilaku Buang Air Besar Pada Masyarakat YangTelah Dan BelumMenerapkan Program Sanitasi Tota IBerbasis Masyarakat (Stbm) Di Kecamatan Inderalaya

Tabel 5 Distribusi Perilaku BAB di Kecematan Inderalaya

\begin{tabular}{ccc}
\hline Kategori & Frekuensi & Presentase \\
\hline Baik & 63 & $63 \%$ \\
\hline Buruk & 37 & $37 \%$ \\
\hline
\end{tabular}


Jurnal Sulolipu : Media Komunikasi Sivitas Akademika dan Masyarakat Vol. 21 No.12021

e-issn : 2622-6960, p-issn : 0854-624X

\begin{tabular}{|c|c|c|}
\hline Total & 100 & $100 \%$ \\
\hline \multicolumn{3}{|c|}{$\begin{array}{l}\text { Hasil penelitian dari Agus Triyono tentang } \\
\text { Faktor-Faktor yang Berhubungan dengar } \\
\text { Perilaku Buang Air Besar Masyarakat Nelayan } \\
\text { di Kampung Garapan Desa Tanjung Pasi } \\
\text { Kabupaten Tangerang Provinsi Banten }\end{array}$} \\
\hline \multicolumn{3}{|c|}{$\begin{array}{l}\text { Tabel } 6 \text { Distribusi Perilaku Buang Air Besar } \\
\text { sembarang Desa Tanjung }\end{array}$} \\
\hline Kategori & rekuensi & Presentase \\
\hline Benar & 29 & $29 \%$ \\
\hline Salah & 71 & $71 \%$ \\
\hline Total & 100 & $100 \%$ \\
\hline
\end{tabular}

Hasil penelitian dari Yulisetyningrum tentang Hubungan Motivasi Perilaku Hidup Bersih dan Sehat (PHBS) dengan Kebiasaan Buang Air Besar (BAB) sembarangan di Dukuh Krajan Desa Karangrowo Kecematan Undaan Kabupaten Kudus

Tabel 7 Distribusi Frekuensi Kebiasaan Buang Air Besar sembarangan

\begin{tabular}{lll}
\hline $\begin{array}{l}\text { Kebiasaan } \\
\text { BAB }\end{array}$ & Frekuensi & Presentase \\
\hline Sembarangan & 18 & $39,1 \%$ \\
\hline $\begin{array}{l}\text { Tidak } \\
\text { sembarangan }\end{array}$ & 28 & $60,9 \%$ \\
\hline Total & 46 & $100,0 \%$ \\
\hline
\end{tabular}

\section{PEMBAHASAN}

Berdasarkan penelitian dari Ambar Winarti dan Suci Nurmalasari tentang Hubungan Perilaku Buang Air Besar (BAB) Dengan Kejadian Penyakit Diare di Desa Krajan Kecamatan Jatinom Kabupaten Klaten dari tabel 5.1 diketahui bahwa $34,7 \%$ responden berperilaku salah. Semakin seseorang berperilaku benar maka tidak mudah terserang suatu penyakit, tetapi jika semakin salah cara berperilaku seseorang tersebut maka mudah terserang penyakit.perilaku seseorang/masyarakat tentang kesehatan ditentukan oleh pengetahuan, sikap, kepercayaan, tradisi dari orang atau masyarakat yang bersangkutan, ketersediaan fasilitas, sikap dan perilaku para petugas kesehatan terhadap kesehatan juga mendukung dan memperkuat terbentuknya perilaku. Perilaku manusia secara operasional dapat dikelompokkan menjadi 3 macam domain, yaitu perilaku dalam bentuk pengetahuan, sikap dan tindakan nyata/perbuatan. Sedangkan tabel 5.2 terdapat $36,7 \%$ responden terkena diare pada saat mengalami berak encer frekuensinya lebih dari tiga kali sehari. Perilaku buang air besar sembarangan mencerminkan adanya budaya masa bodoh masyarakat yang dapat diartikan sebagai sikap tidak peduli apa-apa, tidak ikut memikirkan perkara orang lain, dalam hal ini masyarakat tidak memperdulikan efek yang merugikan akibat buang air besar sembarangan terhadap diri sendiri dan orang lain. Sarana sanitasi, perilaku hidup bersih dan sehat (PHBS) memiliih hubungan yang sangat erat dengan kejadian penyakit diare. Perilaku mencuci tangan sebelum makan, sebelum memberikan makanan kepada bayi dan juga setelah buang air besar menjadi faktor dalam memutuskan rantai penularan penyakit diare. Perilaku membuang kotoran (tinja) pada tempatnya (jamban) juga sangat berpengaruh dalam mencegah penularan penyakit diare. Penyakit yang dapat ditimbulkan antara lain tifoid, paratifoid, diare, kolera, penyakit cacing, hepatitis viral, dan beberapa penyakit infeksi gastrointerstinal lain, serta infeksi parasit lain.

Berdasarkan penelitian dari jurnal Chandra tentang Hubungan Perilaku Opn Defecation terhadap Kejadian Diare di Kecematan Sajad Kabupaten Sambas dari tabel 5.1responden dan anggota keluarganya berperilaku ODF yaitu berjumlah $73 \%$ dan $27 \%$ yang masih berperilaku Open Defecation. Masyarakat tersebut dinyatakan berperilaku Open Defecation karena masih ada anggota keluarganya yang buang air besar tidak di jamban, membuang tinja balita yang tidak di jamban dan penyaluran limbah tinja dari kloset yang tidak ke tangki septik. Perubahan perilaku buang air besar ini tidak mudah, karena sudah bertahun-tahun melakukan perilaku Open Defecation yang merupakan sudah menjadi kebiasaan. Sebagai contoh kalau sudah terbiasa buang air besar di sungai yang kakinya terendam air, merasa dingin, melihat pemandangan dan terasa nyaman lalu harus berpindah defekasi di jamban dengan ruang yang sempit, sumpek dan gelap adalah sangat sulit. Dibutuhkan waktu yang cukup lama untuk mengubah perilaku mengubah perilaku tidak semudah membalik telapaktangan. Pada tabel 5.2 mengenai distribusi kejadian diare didapatkan bahwa 26 keluarga (26\%) yang anggota keluarganya pernah mengalami kejadian diare Hubungan perilaku Open defecation dengan kejadian penyakit diare didapatkan keluarga yang berperilaku Open Defecation yaitu berjumlah 27 keluarga yang pernah mengalami penyakit diare hal ini disebabkan karena kondisi sanitasi lingkungan yang kepemilikan jamban masyarakat tidak semuanya tanpa tangki septik, sumber air 
Jurnal Sulolipu : Media Komunikasi Sivitas Akademika dan Masyarakat

Vol. 21 No.12021

e-issn : 2622-6960, p-issn : 0854-624X

minum kebanyakan dari air sumur dangkal, kebiasaan buang air besar tidak di jamban dan tidak cuci tangan dengan sabun ketika akan atau mau makan dan setelah makan.

Berdasarkan penelitian dari jurnal Resti Irmalasari dkk tentang Studi Komparatif Perilaku Buang Air Besar pada Masyarakat yang Telah dan Belum Menerapkan Program Sanitasi Total Berbasis Masyarakat (STBM) di Kecematan Inderalaya terdapat $63 \%$ masyarakat yang memiliki pengetahuan baik terkait perilaku Buang Air Besar dan 37\% masyarakat yang masih memiliku perilaku buruk terkait Buang Air Besar sembarangan. perilaku hidup bersih dan sehat bukan lagi hal yang asing yang di dengarkan pentingnya penerapan perilaku hidup bersih dan sehat bagi pekerja pengangkut sampah, dapat menunjang agar terhindar dari risiko gangguan kesehatan salah satunya seperti diare.

Berdasarkan penelitian dari jurnal Agus Triyono tentang Faktor-Faktor yang Berhubungan dengan Perilaku Buang Air Besar Masyarakat Nelayan di Kampung Garapan Desa Tanjung Pasir Kabupaten Tangerang Provinsi Banten pada tabel 5.1 diketahui bahwa $71 \%$ masyarakat masih berperilaku salah masyarakat Tanjung lebih banyak bermukim di area pantai sehingga masih banyak yang bertingkah laku buang air besar sembarang tempat . penyebab perilaku buang air besar sembarang tempat karena masih rendahnya pengetahuan masyarakat desa Tanjung hidup sehat, sikap , kepemilikan jamban dan dukungan keluarga dalam bertingkah laku sehat.Jamban keluarga yang tidak memenuhi syarat merupakan penyebab terjadinya pencemaran lingkungan diantaranya pencemaran tanah, pencemaran air, kontaminasi makanan, dan berkembangbiakan lalat. Tinja yang dibuang ditempat terbuka dapat digunakan oleh lalat yang berperan dalam penularan penyakit melalui tinja. Lalat senang menempatkan telurnya pada kotoran manusia yang terbuka, kemudian lalt hinggap di kotoran dan makanan manusia.

Berdasarkan penelitian dari jurnal Yulisetyningrum tentang Hubungan Motivasi Perilaku Hidup Bersih dan Sehat (PHBS) dengan Kebiasaan Buang Air Besar (BAB) sembarangan di Dukuh Krajan Desa Karangrowo Kecematan

Undaan Kabupaten Kudus diketahui tabel 5.1 bahwa masih banyak masyarakat Desa Karangrowo yang beperilaku buang air besar sembarang tempat sebanyak $39,1 \%$ salah satu faktor yang menyebabkan masyarakat melakukan buang air besar sembarang tempat karena rendahnya motivasi masyarakat untuk beperilaku hidup bersih dan sehat. Kebiasaan adalah perilaku masyarakat desa Karangrowo yang sering di ulang-ulang di sengaja maupun tidak disengaja kebiasaan tersebut sudah dilakukan sejak kecil hingga dewasa. Kebiasaan buang air besar sembarangan adalah perilaku masyarakat yang berkaitan dengan kegiatan pembuangan tinja yang tidak sesuai dengan aturan kesehatan (jamban), sehingga masyarakat desa Karangrowo melakukan buang air besar di sungai di rumputrumput dan lain sebagainya.

\section{KESIMPULAN}

Berdasarkan hasil penelitian studi kepustakaan dan analisis variabel yang telah diteliti tentang hubungan perilaku masyarakat dengan kebiasaan buang air besar sembarangan dan kejadian penyakit diare yaitu :

1. Ada hubungan perilaku masyarakat dengan kebiasaan Buang Air Besar (BAB) sembarang tempat

2. Ada hubungan perilaku masyarakat dengan kebiasaan Buang Air Besar (BAB) sembarang tempat dan kejadian penyakit diare

3. Tidak ada hubungan penggunaan air bersih dengan perilaku masyarakat terhadap Buang Air Besar (BAB) sembarang

\section{SARAN}

1. Bagi Institusi terkait (Puskesmas, Dinas Kesehatan)

Hendaknya petugas kesehatan melakukan penyuluhan atau pendidikan kesehatan untuk memotivasi masyarakat dalam berperilaku Buang Air Besar yang benar.

2. Bagi Masyarakat

Merubah kebiasaan Buang Air Besar (BAB) sembarangan menjadi Perilaku Hidup Bersih dan Sehat (PHBS)

\section{DAFTAR PUSTAKA}

Agustini Aat, 2015. Promosi Kesehatan, Yogyakarta : CV Budi Utama

Alhamda Syukra, dkk, 2015. IImu Kesehatan Masyarakat, Sumatera Barat : Deepublish 
Jurnal Sulolipu : Media Komunikasi Sivitas Akademika dan Masyarakat

Vol. 21 No. 12021

e-issn : 2622-6960, p-issn : 0854-624X

Ambar Wiranti dan Suci Nurmalasari,2016. Hubungan Perilaku Buang Air Besar (BAB) dengan Kejadian Diare di Desa Krajan Kecamatan Jatinom Kabupaten Klaten. Jurnal Involasi Kebidanan

Anonim,2014. TeoriSikap.http://www.erwinmiradi.com/topik/teori+sikap+soekidjp+notoatmodjo.html. Diakses Tanggal 07 Januari 2020

Anonim,2014.DefenisiPengetahuan,http://www.infogigi.com/articel/definisi-pengetahuan-menurutnotoatmodjo. htm/ Diakses Tanggal 07 Januari 2020.

Ariani Ayu Putri,2016. Diare (Pencegahan dan Pengobatannya). Yogyakarta : Nuha Medika

Badan Pusat Statistik Nasional (BPS), Sensuk Penduduk, 2010

Chandra Widi Raharjo dan Abror Irsan 2016. Hubungan Perilaku Open Defecation terhadap kejadian Diare di Kecematan Sajad Kabupaten Sambas.

Chitra Dewi dan Josep Andreson Naraha 2019. Analisis Faktor Lingkungan terhadap Perilaku Buang Air Besar sembarangan Masyrakat Desa Lermatang Kabupaten Maluku Tenggara Barat. Jurnal Info Kesehatan. 2887-877

Dinas Kesehatan Kota Makassar, 2015. Profil Kesehatan Kota Makassar 2015. (Online) :https://www.google.com/search?client=firefox-bd\&q=dinkes+kota+makassar+2015+diare+yang+ditemukan+dan+ditangani.Diakses Januari 2020

Dinas Kesehatan Provinsi Sulawesi Selatan, 2017. Profil Kesehatan Provinsi Sulawesi Selatan 2017. (Online) : https://pusdatin.kemkes.go.id/resources/download/pusdatin/profil-kesehatanindonesia/Data-dan-Informasi Profil-Kesehatan-Indonesia-2017.pdf. Diakses 13 Januari 2020

Dinas Kesehatan Provinsi Sulawesi Selatan, 2018. Profil Kesehatan Provinsi Sulawesi Selatan 2018. (Online) : https://bps.go.id/statictable/2016/01/25/1900/persentase-rumah-tangga-menurutprovinsi-dan-memiliki-akses-terhadap-sanitasi-layak-1993-2018.html. Diakses 11 Januari $\underline{2020}$

Entjang Indan, 2000, IImu Kesehatan Makassar, Bandung : PT.Citra Aditya Bakti

Ernawati, 2019. Faktor-faktor yang mempengaruhi Kebiasaan Buang Air Besar Sembarangan Tempat Di Desa Bonto Jai Kecamatan Bissappu Kabupaten Bantaeng . Makassar: Program D-III Jurusan Kesehatan Lingkungan Politeknik Kesehatan Makassar (KTI tidak diterbitkan)

Hadianti Sukma, dkk 2018. Hubungan Pengetahuan, Sikap BAB, dan Kepemilikan Septic Tank dengan status ODF di Kecematan Candisari Kota Semarang. Jurnal Kesehatan Masyarakat 23563346

Kemenkes RI, 2014, Profil Kesehatan Indonesia Tahun 2016. (Online) : https://scholar.google.co.id/scholar?hl=en\&as_sdt=0\%2C5\&as_vis=1\&q=kemenkes+provinsi+ 2014++perilaku+buang+air+besar\&btnG=. D Januari 2020

Kemenkes RI, 2016, Profil Kesehatan Indonesia Tahun 2016. (Online) : https://scholar.google.co.id/scholar?q=kemenkes+2016+jumlah+kasus+penderita+penyakit+di are+di+indonesia\&hl=en\&as sdt=0\&as vis=1\&oi=scholart . Diakses 14 Januari 2020

Muh Rijaluddin, 2013. Studi pengetahuan, sikap, Dan pendidikan Masyarakat Terhadap Pemanfaatan Jamban Keluarga Di Desa Siawung Kecamatan Barru Kabupaten Barru 2013.Makassar: 
Jurnal Sulolipu : Media Komunikasi Sivitas Akademika dan Masyarakat

Vol. 21 No. 12021

e-issn : 2622-6960, p-issn : 0854-624X

Program D-III Jurusan Kesehatan Lingkungan Politeknik Kesehatan Makassar (KTI tidak diterbitkan)

Muslimin, 2015. Perilaku Antropologi Sosial Budaya dan Kesehatan, Yogyakarta : CV Budi Utama.

Resti Irmalasari, dkk 2011. Studi Komperatif Perilaku Buang Air Besar pada Masyarakat yang Telah dan belum Menerapkan Program Sanitasi Total Berbasis Masyarakat (STBM) di Kecematan Inderalaya. Jurnal IImu Kesehatan Masyarakat.

Ronny Muntu, 2015. Dasar-Dasar Kesehatan Lingkungan. Makassar:Kementerian Kesehatan Republik Indonesia Politeknik Kesehatan Makassar Jurusan Kesehatan Lingkungan.

Soegijanto Soegeng, 2016. Penyakit Tropis dan Infeksi di Indonesia, Surabaya : Airlangga University Press

Soekidjo Notoamodjo, 2014. Promosi kesehatan \& Perilaku Kesehatan. Jakarta : Rineka Cipta

Wahyuni Sahani, dkk, 2018. Pedoman Karya Tulis IImiah Diploma III.Makassar : Kementerian Kesehatan Republik Indonesia Politeknik Kesehatan Makassar Jurusan Kesehatan Linkungan

WHO,

$2010 \quad$ (Online)

https://www.google.com/search?client=firefox-b$\underline{\mathrm{d} \& \mathrm{q}=\text { data }+ \text { who }+2010+\mathrm{bab}+\text { sembarangan }}$ 